\title{
Plasma prolactin changes in anoestrous ewes after infusion of genistein into the third ventricle*
}

\author{
K. Romanowicz ${ }^{1}$, T. Misztal ${ }^{1}$, B. Barcikowski ${ }^{1}$ and A. Madej ${ }^{2,3}$

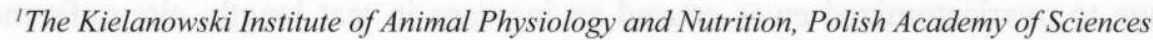 \\ 05-110 Jablonna, Poland \\ ${ }^{2}$ Department of Anatomy and Physiology, Swedish University of Agricultural Sciences (SLU), \\ Centre for Reproductive Biology in Uppsala (CRU) \\ P.O. Box 7011, SE-750 07 Uppsala, Sweden
}

(Received 4 February, 2004; revised version 13 September 2004; accepted 25 October 2004)

\begin{abstract}
Genistein, one of isoflavones, is structurally similar to mammalian endogenous oestrogens, which inhibit activity of tyrosine kinase, DNA topoisomerases, and possess antioxidant activity and oestrogenic activity. The aim of the present work was to study effects of the central administration of genistein on prolactin secretion in ewes during the seasonal anoestrus. The experiment was carried out on twelve Polish Lowland ewes. Infusions of genistein into the third ventricle of ewes were performed with calibrated $1.0-\mathrm{ml}$ gas-tight syringes and a microinjection pump. Control infusions $(\mathrm{n}=4)$ from 12.01 to $16.01 \mathrm{~h}$ were done with a Ringer-Locke solution at flow rate $100 \mu \mathrm{l} / \mathrm{h}$. The dose of genistein was $1 \mu \mathrm{g} / 100 \mu \mathrm{l} / \mathrm{h}(\mathrm{n}=6)$ and $10 \mu \mathrm{g} / 100 \mu \mathrm{l} / \mathrm{h}(\mathrm{n}=5)$ during 4-h infusions. Before the infusions, differences in prolactin concentration between control and experimental animals were insignificant. Prolactin concentrations were significantly $(\mathrm{P}<0.05)$ elevated after $2 \mathrm{~h}$ of genistein infusion $(1 \mu \mathrm{g} / \mathrm{h})$ as compared with the control group. The higher dose of genistein $(10 \mu \mathrm{g} / \mathrm{h})$ evoked an immediate increase of prolactin concentrations, which remained elevated $(\mathrm{P}<0.05)$ until the end of samples collection at $20.00 \mathrm{~h}$. There was also significant $(\mathrm{P}<0.05)$ difference in prolactin concentrations, during the last $2 \mathrm{~h}$ of the blood collection, between ewes with different genistein doses. In conclusion, centrally administered genistein, stimulate the secretion of prolactin in dose-dependent manner in ewes during the seasonal anoestrus.
\end{abstract}

KEY WORDS: prolactin, genistein, intracerebroventricular, ewe

\footnotetext{
" Supported by Formas, the Swedish Research Council for Environment, Agricultural Sciences and Spatial Planning (formerly the Swedish Council for Forestry and Agricultural Research (Grant D No. 31.0412/97). The experimental part was carried out at The Kielanowski Institute of Animal Physiology and Nutrition, Polish Academy of Sciences, Jabłonna (Poland) and supported by the State Committee for Scientific Research, Grant No. 6 PO6D 01120

${ }^{3}$ Corresponding author: e-mail: Andrzej.Madej@afys.slu.se
} 


\section{INTRODUCTION}

Isoflavones compounds, a class of phytoestrogens, which include formononetin, biochanin A, daidzein and genistein, occur in red clover (Trifolium pratense), and might be causing infertility in female sheep (Adams, 1995). In the earlier study Mathieson and Kitts (1980) found that genistein and coumestrol could bind to oestrogen receptors in pituitary and hypothalamic cytosol of the ewe. In general, phytoestrogens mimic the actions of oestradiol. Their affinity to oestrogen receptor alfa $(E R \alpha)$ as well as the oestrogen receptor beta (ERB) is substantial (Kuiper et al., 1998). In a previous study we have shown that feeding red clover silage to ovariectomized ewes caused an increase in teat length, circumference and even stimulated a milky fluid secretion (Nwannenna et al., 1995). These changes were similar to that during treatment with oestradiol-17 $\beta$ implant. Ingestion of phytoestrogens stimulated also secretion of thyroid hormones and tended to increase follicle size and ER $\alpha$ immunoreactivity of thyroid glands of ovariectomized ewes (Madej et al., 2002). Treatment of intact and ovariectomized ewes with different doses of oestradiol-17 $\beta$ resulted in a stimulation of prolactin's secretion (Baird et al., 1981; Elsasser et al., 1983; Rozell and Keisler, 1990). The aim of the present work was to study effects of the central administration of genistein on prolactin changes in intact ewes during the seasonal anoestrus.

\section{MATERIAL AND METHODS}

\section{Animals, management and experimental procedure}

Twelve Polish Lowland ewes were used in this experiment during the period corresponding to anoestrus. A steel guide cannulae (1.6 mm o.d.) was implanted under stereotaxic control in the third brain ventricle through a drill hole in the skull under general anaesthesia (Traczyk and Przekop, 1963; Welento et al., 1969; Misztal et al., 1997). General anaesthesia was induced with Vetbutal plus ketamine (Biowet, Poland). The guide cannula was fixed to the skull with stainless steel screws and dental cement. The external opening to the canal was closed with a stainless steel cup. After surgery, usually lasting 45 to $70 \mathrm{~min}$, animals were injected with pain-relieving drugs and antibiotics (Betamox - ScanVet, Poland). The post-operative period was a minimum 10 days, under veterinary surveillance. Sixteen days after surgery, adequately recovered animals were used in the experimental studies.

Infusions of genistein into the third ventricle of ewes were performed with calibrated $1.0-\mathrm{ml}$ gas-tight syringes and a microinjection pump CMA/100 (CMA/ Microdialysis AB, Stockholm, Sweden). Control infusions (C-group, $n=4$ ) were 
done with a Ringer-Locke solution from 12.01 to $16.01 \mathrm{~h}$ at flow rate $100 \mu \mathrm{l} / \mathrm{h}$. The dose of genistein (Sigma-Aldrich Corp. St. Louis, MO, USA) of concentration $1 \mu \mathrm{g} / 100 \mu \mathrm{l} / \mathrm{h}$ (GEN1-group, $\mathrm{n}=6$ ) and $10 \mu \mathrm{g} / 100 \mu \mathrm{l} / \mathrm{h}$ (GEN10-group, $\mathrm{n}=5$ ) was infused during $4 \mathrm{~h}$. Before infusion, an appropriate genistein solution was prepared from the stock solution in ethanol $(20 \mathrm{mg} / \mathrm{ml})$, kept in $-20^{\circ} \mathrm{C}$. During the experiments, animals were kept in cages of comfortable sizes, in which they could lie down and have free access to hay and water. Blood samples $(3 \mathrm{ml})$ were collected from the jugular vein, through a catheter, at 10 -min intervals from 08.00 to $20.00 \mathrm{~h}$. Plasma samples were stored at $-20^{\circ} \mathrm{C}$ until assayed for prolactin by radioimmunoassay.

The Ethics Committee of the Kielanowski Institute of Animal Physiology and Nutrition approved all described procedures at Jabłonna, according to the Polish Guide of Care and Use of Animals (August 2, 1997).

\section{Prolactin determination}

Plasma prolactin concentrations were assayed by a radioimmunoassay doubleantibody method, using antiovine-PRL and antirabbit-gammaglobulin antiserum according to Wolinska et al. (1977). The prolactin standard was produced by Professor Kochman from the Kielanowski Institute of Animal Physiology and Nutrition (Kochman and Kochman, 1977) and is routinely applied in the analysis. The intra- and interassay coefficients of variation were 9.0 and $12.0 \%$, respectively. The lowest detectable amount of prolactin was $2 \mu \mathrm{g} / \mathrm{l}$.

\section{Statistical analysis}

The hormonal observations were first log transformed and then the repeated measurement analysis of variance was performed using the MIXED procedure on the generated averages according to the Statistical Analysis System program package (Release 6.12, 1996, SAS Institute Inc., Cary, NC, USA). The statistical model included dose (3 groups), time (twelve 1-h periods), the interaction between dose and time, and the random effect of ewe within dose. From the analysis of variance, the results of prolactin concentrations, presented as least squares means (LS means) \pm SEM, were back transformed.

\section{RESULTS}

No significant difference in the plasma concentration of prolactin was seen during four h prior infusions between the C-group and the GEN1-group (Figure 1). During that time, prolactin concentrations varied between 44.7 and $165.3 \mu \mathrm{g} / \mathrm{l}$ with maximum values before $10.00 \mathrm{~h}$. Infusion of Ringer-Locke solution did not changed significantly 
prolactin secretion; its concentration varied between 39.0 and $77.0 \mu \mathrm{g} / \mathrm{l}$ (Figure 1). On the other hand, infusion of $1 \mu \mathrm{g} / \mathrm{h}$ of genistein into the third ventricle did result in the significant increase in prolactin from the initial concentration of $67.7 \pm 25.1 \mu \mathrm{g} / \mathrm{l}$ at $12.00 \mathrm{~h}$ to $142.0 \pm 25.1 \mu \mathrm{g} / \mathrm{l}$ at $16.00 \mathrm{~h}(\mathrm{P}<0.05)$. Afterwards, prolactin concentration gradually decreased, reaching a level comparable to that of control ewes at $18.00 \mathrm{~h}$ (Figure 1). In the GEN1-group, two h after genistein infusion was stopped, prolactin concentrations were, overall, significantly $(\mathrm{P}<0.05)$ elevated, compared with that of the C-group.

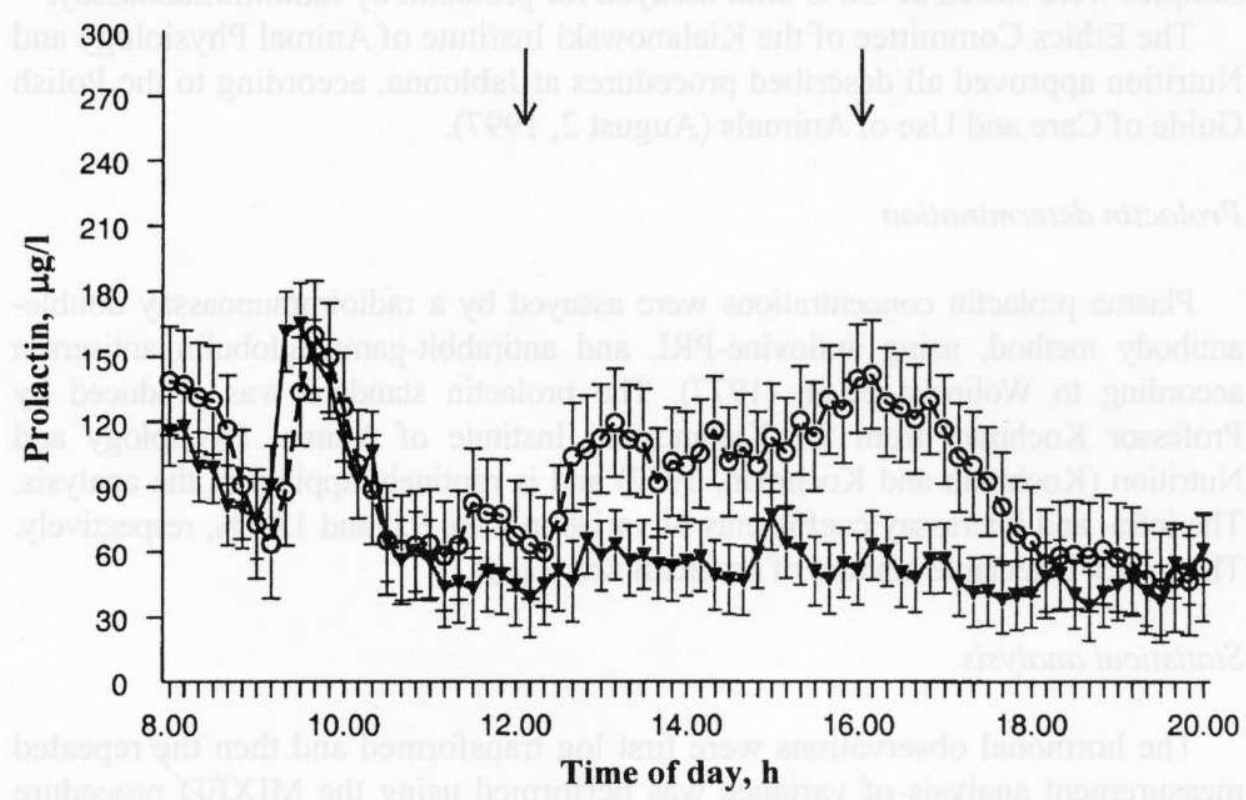

Figure 1. Concentrations of prolactin (LS means \pm SEM) in 10-min plasma samples over 12-h sampling in ewes during an infusion either of Ringer-Locke solution (from 12.01 to $16.01 \mathrm{~h})(\boldsymbol{\nabla}-\mathbf{\nabla})$ or genistein $(1 \mu \mathrm{g} / \mathrm{h}$ from 12.01 to $16.01 \mathrm{~h})(\mathrm{O}----\circ)$. Arrows point to beginning and termination of the infusions

No significant difference in the plasma concentration of prolactin was seen during four $\mathrm{h}$ prior infusions between the C-group and the GEN10-group (Figure 2). Infusion of $10 \mu \mathrm{g} / \mathrm{h}$ of genistein into the third ventricle resulted in the immediate increase of prolactin concentration, from the initial $62.0 \pm 43.2 \mu \mathrm{g} / \mathrm{l}$ at $12.00 \mathrm{~h}$ to $150.0 \pm 43.2 \mu \mathrm{g} / \mathrm{l}$ at $13.00 \mathrm{~h}(\mathrm{P}<0.05)$. Before the infusion was stopped at $16.00 \mathrm{~h}$, the concentration of prolactin had reached $220.0 \pm 43.2 \mu \mathrm{g} / \mathrm{l}(\mathrm{P}<0.05)$. After $16.00 \mathrm{~h}$, prolactin concentrations were still elevated $(140.0-210.0 \mu \mathrm{g} / \mathrm{l})$ until $20.00 \mathrm{~h}$, when the last samples were collected. Overall, in the GEN10-group, beginning two $\mathrm{h}$ after start of infusion, prolactin concentrations were significantly $(\mathrm{P}<0.05)$ elevated, compared with that of the C-group. During the last $2 \mathrm{~h}$ of 


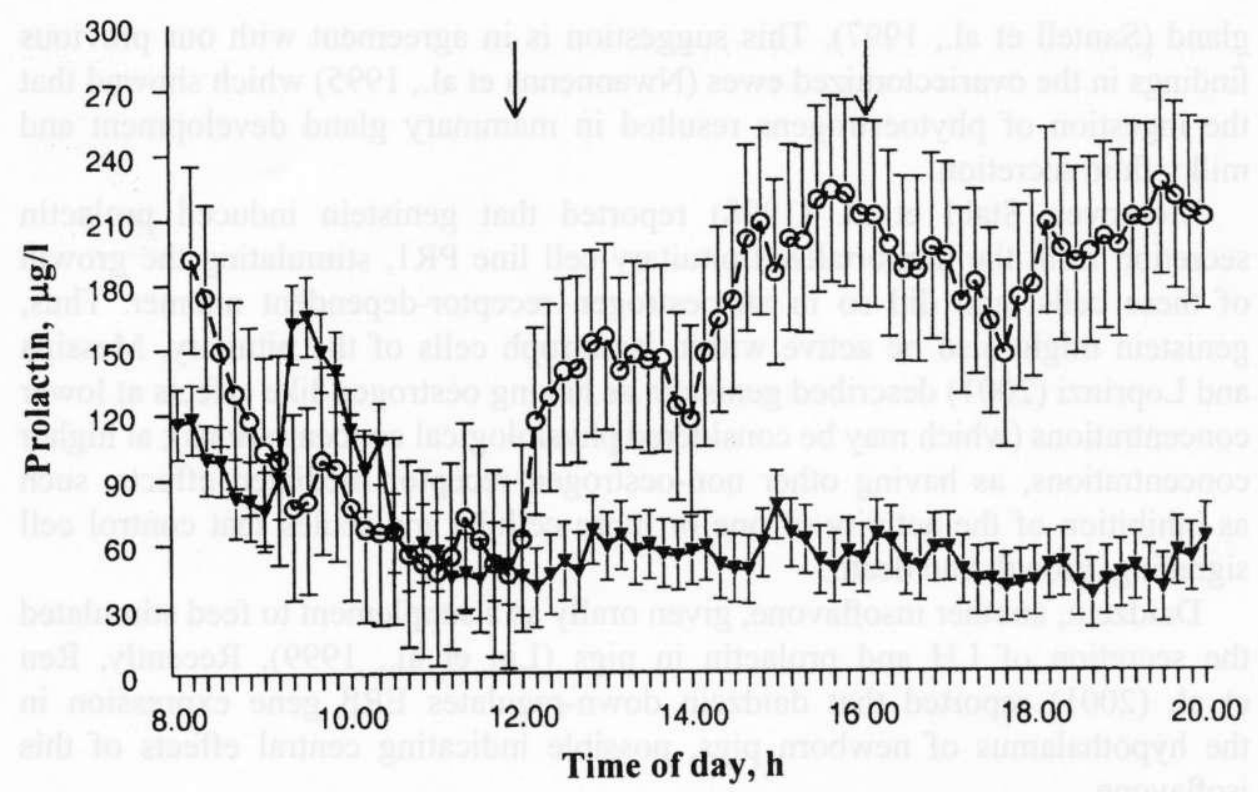

Figure 2. Concentrations of prolactin (LS means \pm SEM) in 10-min plasma samples over 12-h sampling in ewes during an infusion either of Ringer-Locke solution (from 12.01 to $16.01 \mathrm{~h})(\mathbf{\nabla}-\mathbf{\nabla})$ or genistein $(10 \mu \mathrm{g} / \mathrm{h}$ from 12.01 to $16.01 \mathrm{~h})(\circ----\circ)$. Arrows point to beginning and termination of the infusions

experimental day ( $18.00 \mathrm{~h}$ to $20.00 \mathrm{~h}$ ), prolactin concentrations in the GEN10-group were significantly $(\mathrm{P}<0.05)$ higher then that in GEN-1 (Figure 1 vs Figure 2).

\section{DISCUSSION}

The results from the present study show that the centrally administered genistein stimulates the secretion of prolactin in ewes during seasonal anoestrus. Several hypotheses can be advanced to explain this stimulatory effect of genistein. In the case of ovariectomized rats, ingestion of either genistein or oestradiol resulted in the stimulation of prolactin secretion (Santell et al., 1997). Santell's et al. (1997) concluded that genistein's action in the hypothalamus and pituitary is similar to that of oestradiol, leading to the synthesis and release of prolactin from the adenohypohysis in rats. Their conclusion was based on the findings of Jones and Naftolin (1990), who demonstrated that oestradiol acts on the synthesis and release of prolactin by decreasing the activity of tyrosine hydroxylase, which in turn decreases the concentration of dopamine in the hypothalamus. Thus, genistein's ability to inhibit mammary gland regression postovariectomy might be mediated through prolactin, which exerts its mitogenic effects on the mammary 
gland (Santell et al., 1997). This suggestion is in agreement with our previous findings in the ovariectomized ewes (Nwannenna et al., 1995) which showed that the ingestion of phytoestrogens resulted in mammary gland development and milky fluid secretion.

Moreover, Stahl et al. (1998) reported that genistein induced prolactin secretion from the immortalized pituitary cell line PR 1 , stimulating the growth of these cells, and did so in an oestrogen receptor-dependent manner. Thus, genistein might also be active within lactotroph cells of the pituitary. Messina and Loprinzi (2001) described genistein as having oestrogen-like effects at lower concentrations (which may be considered physiological concentrations); at higher concentrations, as having other non-oestrogen receptor mediated effects, such as inhibition of the activity of one or more cellular molecules that control cell signaling, growth and death.

Daidzein, another insoflavone, given orally as a supplement to feed stimulated the secretion of LH and prolactin in pigs (Liu et al., 1999). Recently, Ren et al. (2001) reported that daidzein down-regulates ER $\beta$ gene expression in the hypothalamus of newborn pigs, possible indicating central effects of this isoflavone.

In earlier findings of Wolinska et al. (1977) it was suggested that in sheep the inhibitory system controlling the secretion and production of prolactin exist in the caudal medial basal hypothalamus. Indeed, the suppression of prolactin concentrations following infusion of D2-like (quinpirole) agonist into $\mathrm{MBH}$ (Anderson et al., 1997) supports findings of Wolinska et al. (1977) and Curlewis et al. (1991). Dopamine might also act through dopamine D2 receptors located on lactotrophs in the anterior pituitary in the ewe (Anderson et al., 1997; Bertrand et al., 1999). On the other hand a stimulatory system controlling the secretion and production of prolactin in sheep was suggested to operate via dopamine D1 receptc: $\mathrm{s}$ in the ventromedial hypothalamus (VMH) (Curlewis et al., 1995).

Intraventricular administration of oestradiol for 3 days resulted in an increase of serum prolactin in rats, consistent with the change in the prolactin mRNA level (Maeda et al., 1996). However, Blum et al. (1987) showed that a decrease in tyrosine hydroxylase gene transcription in rat hypothalamus occurred 20 min after oestrogen treatment and reached $5 \%$ of control level after an hour. In ovariectomized ewes, oestradiol treatment during long days resulted in reduction of pulsatile LH secretion, without affecting prolactin, due to stimulation of tyrosine hydroxylase in the lateral retroschiasmatic area (Gayrard et al., 1994).

Interestingly, melatonin infused into the third ventricle in anoestrous ewes stimulated the prolactin secretion within $30 \mathrm{~min}$, and maintained high concentrations for an additional 2 to $3 \mathrm{~h}$ (Misztal et al., 1997). In the present study, the response of prolactin to the low-dose infusion of genistein $(1 \mu \mathrm{g} / \mathrm{h})$ resembled changes found during melatonin infusion at the dose of $100 \mu \mathrm{g} / \mathrm{h}$ (Misztal et al., 
1997), whereas the high-dose infusion of genistein $(10 \mu \mathrm{g} / \mathrm{h})$ resulted in a very high elevation of prolactin, which lasted even $4 \mathrm{~h}$ after the infusion of genisten was terminated. Misztal et al. $(1997,2001)$ found that the stimulation of prolactin secretion by melatonin was not mediated by the changes in dopamine release. Endogenous opioid peptides were not a major component of this melatonin action either (Misztal et al., 2001). It might be possible that TRH (Robinson et al., 1996) mediated this melatonin action.

Recently, Romanowicz et al. (2004) reported that in ovariectomized ewes during seasonal anoestrus, infused with $10 \mu \mathrm{g}$ of genistein, i.e. the same dose as we used in the present study, the plasma prolactin concentrations were increased during and after infusion of genistein. It was suggested that the short-term stimulatory effect of genistein on prolactin secretion might be mediated through an inhibition of dopamine neurons.

The results from the present study lead us to conclusion that the centrally administered genistein may stimulate the secretion of prolactin in intact ewes during the seasonal anoestrus. To explain, however, the neuroendocine effects of genistein in sheep, further studies need to be conducted.

\section{ACKNOWLEDGMENTS}

We wish to thank Dr. J. Rutkowski for help in the brain surgery and Mrs W. Jezierska and Mrs G. Krawczak for help in the collection and storage of blood samples as well as for technical assistance with the radioimmunoassay.

\section{REFERENCES}

Adams N.R., 1995. Detection of the effects of phytoestrogens on sheep and cattle. J. Anim. Sci. 73, $1509-1515$

Anderson S.T., Sawangjaroen K., Curlewis J.D., 1997. A method for drug infusion into the lateral median eminence and arcuate nucleus of sheep. J. Neurosci. Meth. 71, 169-176

Baird D.T., Swanston I.A., McNeilly A.S., 1981. Relationship between LH, FSH, and prolactin and the secretion of androgens and estrogens by the preovulatory follicle in the ewe. Biol. Reprod. 24, 1013-1025

Bertrand F., Thiery J.C., Picard S., Malpaux B., 1999. Implication of D2-like dopaminergic receptors in the median eminence during the establishment of long-day inhibition of LH secretion in the ewe. J. Endocrinol. 163, 243-254

Blum M., McEwen B.S., Roberts J.L., 1987. Transcriptional analysis of tyrosine hydroxylase gene expression in the tuberoinfundibular dopaminergic neurons of the rat arcuate nucleus after estrogen treatment. J. Biol. Chem. 262, 817-821

Curlewis J.D., Naylor A.M., McNeilly A.S., 1991. Evaluation of a possible role of the dopamine D1 and D2 receptors in the steroid-dependent suppression of luteinizing hormone secretion in the seasonally anoestrous ewe. J. Neuroendocrinol. 3, 387-391 
Curlewis J.D., Thiery J.C., Malpaux B., 1995. Effect of hypothalamic infusion of a dopamine D1 receptor antagonist on prolactin secretion in the ewe. Brain Res. 697, 48-52

Elsasser T.H., Bolt D.J., Bradley B.D., Roper M., 1983. Luteinizing hormone, follicle stimulating hormone and prolactin secretion in ewes and wethers after zeranol or estradiol injection. J. Anim. Sci. 57, 443-448

Gayrard V., Malpaux B., Tillet Y., Thiéry J.C., 1994. Estradiol increases tyrosine hydroxylase activity of the A15 nucleus dopaminergic neurons during long days in the ewe. Biol. Reprod. $50,1168-1177$

Jones E.E., Naftolin F., 1990. Estrogen effects on the tuberoinfundinbular dopaminergic system in the female rat brain. Brain Res. 510, 84-91

Kochman H., Kochman K., 1977. Purification of ovine and bovine prolactins on DEAE cellulose chromatography and preparative polyacrylamide gel electrophoresis. Bull. Acad. Sci. Pol. 25, $67-70$

Kuiper G.G.J.M., Lemmen J.G., Carlsson B., Corton J.C., Safe S.H., van der Saag P.T., van der Burg B., Gustafsson J-A., 1998. Interaction of estrogenic chemicals and phytoestrogens with estrogen receptor $\beta$. Endocrinology $139,4252-4263$

Liu G.T., Zheng Y.L., Chen W.H., Chen J., Han Z.K., 1999. Effect of daidzein fed to pregnant sows on milk production and the levels of hormones in colostrum. J. Nanjing Agr. Univ. 22, 69-72

Madej A., Persson E., Lundh T., Ridderstråle Y., 2002. Thyroid gland function in ovariectomized ewes exposed to phytoestrogens. J. Chromatogr. B 777, 281-287

Maeda T., Ikegami H., Sakata M., Yamaguchi M., Wada K., Koike K., Adachi K., Kurachi H., Hirota K., Miyake A., 1996. Intraventricular administration of estradiol modulates rat prolactin secretion and synthesis. J. Endocrinol. Invest. 19, 586-592

Mathieson R.A., Kitts W.D., 1980. Binding of phyto-oestrogen and oestradiol-17 beta by cytoplasmic receptors in the pituitary gland and hypothalamus of the ewe. J. Endocrinol. 85, 317-325

Messina M.J., Loprinzi C.L., 2001. Soy for breast cancer survivors: A critical review for the literature. J. Nutr. 131, 3095S-3108S

Misztal T., Romanowicz K., Barcikowski B., 1997. Natural and melatonin-stimulated changes in the circadian rhythm of prolactin secretion in the ewe during seasonal anestrus. Neuroendocrinology $66,360-367$

Misztal T., Romanowicz K., Barcikowski B., 2001. Short-term modulation of prolactin secretion by melatonin in anestrous ewes following dopamine- and opiate receptor blockade. Exp. Clin. Endocrinol. Diab. 109, 174-180

Nwannenna A., Lundh TJ.-O., Madej A., Fredriksson G., Björnhag G., 1995. Clinical changes ovariectomized ewes exposed to phytoestrogens and $17 \beta$-estradiol implants. Proc. Soc. Exp. Biol. Med. 208, 92-97

Ren M.Q., Kuhn G., Wegner J., Nurnberg G., Chen J., Ender K., 2001. Feeding daidzein to late pregnant sows influences the estrogen receptor beta and type 1 insulin-like growth factor receptor mRNA expression in newborn piglets. J. Endocrinol. 170, 129-135

Robinson J.J., Aitken R.P., Atkinson T., Wallace J.M., McNeilly A.S., 1996. Effect of continuous infusion of thyrotropin-releasing hormone on plasma prolactin and ovarian activity in melatonintreated ewes. J. Reprod Fertil. 107, 17-22

Romanowicz K., Misztal T., Barcikowski B., 2004 Genistein, a phytoestrogen, effectively modulates luteinizing hormone and prolactin secretion in ovariectomized ewes during seasonal anestrus. Neuroendocrinology 79, 73-81

Rozell T.G., Keisler D.H., 1990. Effects of estradiol on LH, FSH and prolactin in ovariectomized ewes. J. Reprod. Fertil. 88, 645-653 
Santeil R.C., Chang Y.C., Nair M.G., Helferich W.G., 1997. Dietary genistein exerts estrogenic effects upon the uterus, mammary gland and the hypothalamic/pituitary axis in rats. J. Nutr. 127, 263-269

Stahl S., Chun T.-Y., Gray W.G., 1998. Phytoestrogens act as estrogen agonists in an estrogen resposive pituitary cell line. Toxicol. Appl. Pharmacol. 152, 41-48

Traczyk W., Przekop F., 1963. Methods for investigation of the function of the hypothalamus and hypophysis in chronic experiments in sheep. Acta Physiol. Pol. 14, 217-226

Welento J., Szteyn S., Milart Z.. 1969. Observations on stereotaxic configuration on the hypothalamic nuclei in the sheep. Anat. Anz. 124, 1-27

Wolinska E., Polkowska J., Domanski E., 1977. The hypothalamic centres involved in the control of production and release of prolactin in sheep. J. Endocrinol. 73, 21-29

\section{STRESZCZENIE}

\section{Zmiany stężenia prolaktyny w krwi u anestralnych owiec po infuzji genisteiny do trzeciej komory mózgowej}

Genisteina, należąca do grupy związków izoflawonowych, jest strukturalnie podobna do endogennych estrogenów, hamuje aktywność kinazy tyrozynowej, topoizomerazy DNA oraz ma właściwości antyoksydacyjne. Celem pracy było zbadanie wpływu genisteiny, podawanej bezpośrednio do ośrodkowego układu nerwowego, na sekrecję prolaktyny u owiec w okresie anestralnym. Doświadczenie przeprowadzono na 12 owcach rasy polska nizinna. Infuzje genisteiny lub płynu Ringera-Locke'a (kontrola, $n=4$ ) do trzeciej komory mózgowej wykonywano przy pomocy pompy mikroiniekcyjnej od godziny 12.01 do 16.01 , w tempie $100 \mu 1 /$ godz. Podano dwie dawki genisteiny, $1 \mu \mathrm{g} / 100 \mu \mathrm{l} / \operatorname{godz}$. $(4 \mu \mathrm{g}, \mathrm{n}=6)$ lub $10 \mu \mathrm{g} / 100 \mu \mathrm{l} / \mathrm{godz}$. $(40 \mu \mathrm{g}, \mathrm{n}=5)$. Próbki krwi pobierano z żyły szyjnej od godz. 8.00 do 20.00. poprzez kateter zalożony dzień przed doświadczeniem. Nie stwierdzono istotnych różnic $w$ stężeniu prolaktyny przed infuzją między grupami doświadczalną i kontrolną. U owiec, które otrzymały mniejszą dawkę genjsteiny, stwierdzono istotny $(\mathrm{P}<0,05)$ wzrost stężenia prolaktyny w ciągu dwóch godzin po zakończeniu infuzji, w porównaniu 7 owcami kontrolnymi. Wiçksza dawka genisteiny spowodowała wyraźny wzrost stężenia prolaktyny bezpośrednio po rozpoczęciu infuzji. Stężenie prolaktyny utrzymywało się następnie na poziomie istotnie $(\mathrm{P}<0,05)$ wyższym niż. u owicc kontrolnych, do zakończenia doświadczenia (godz. 20.00). Istotne różnice $(\mathrm{P}<0,05) \mathrm{w}$ stężeniu prolaktyny stwierdzono również między owcami otrzymującymi różne dawki genisteiny w ciągu ostatnich dwóch godzin kolekcji krwi. Uzyskane wyniki wskazują, że genisteina infundowana do ośrodkowego układu nerwowego anestralnych owiec stymuluje sekrecję prolaktyny w sposób zależny od dawki. 